\title{
$\mathrm{MgO}: \mathrm{LiNbO}_{3}$ への短周期分極反転形成と高効率紫外光発生
}

\author{
森川顕洋，杉田 知也，水内 公典，山本和久 \\ 松下電器産業(株)メディア制御システム開発センター( ₹570-8501 大阪府守口市八雲中町3-1-1)
Fabrication of First-Order Periodically Poled MgO: $\mathrm{LiNbO}_{3}$ Bulks for Ultraviolet Light Generation

\author{
Akihiro MORIKAWA, Tomoya SUGITA, Kiminori MIZUUCHI, and Kazuhisa YAMAMOTO \\ Storage Media Systems Development Center, Matsushita Electric Industrial Co. Ltd. \\ 3-1-1, Yagumo-Nakamachi, Moriguchi, Osaka 570-8501
}

(Received September 12, 2003)

\begin{abstract}
We propose a novel method for controlling the shape of a short period domain-inverted structure utilizing a multi-pulse poling method. Using this technique, periodically domain-inverted structures with periods of 1.4$2.4 \mu \mathrm{m}$ were fabricated for over $10 \mathrm{~mm}$ interaction length in $2 \mathrm{~mm}$ thick Z-cut $\mathrm{MgO}: \mathrm{LiNbO}_{3}$ crystal. We have demonstrated highly efficient ultraviolet light generation $(340-390 \mathrm{~nm}$ ) using bulk QPM-SHG devices with these structures. Continuous wave $72 \mathrm{~mW}$ at wavelength of $372 \mathrm{~nm}$ was generated with conversion efficiency of $17 \%$.
\end{abstract}

Key Words: QPM, SHG, Domain inversion, $\mathrm{MgO}$ : $\mathrm{LiNbO}_{3}$, Ultraviolet light

1.はじめに

近年，光源の短波長化により光ディスクの高密度化が 加速され，2003年には青紫色レーザーを用いたブルーレ イディスクが $20 \mathrm{~GB}$ 以上の大容量で商品化された. 次世代 の高密度記録用光源として, さらなる短波長光源が要望 されている。また, DNA鑑定, 蛋白質等の構造解析をは じめとするバイオ分野に関する研究においても，高い フォトンエネルギーと高分解能を有する紫外レーザーが キーデバイスとして注目されている. さらに, 露光, ホ ログラム記録, 加工, 計測等の幅広い分野においても紫 外レーザーは必要とされている。

全固体型紫外レーザーを実現する手法として, 非線形 光学効果を利用した高調波発生がある. 固体レーザーや 半導体レーザーを基本波光源に用い, 第二高調波発生あ るいは第三高調波発生により短波長光発生を実現し, 高 効率変換はQスイッチパルスを利用した擬似CW光源によ り達成される。しかしながら，紫外光発生領域における 高効率な波長変換素子が実存しないため, 高出力の紫外 $\mathrm{CW}$ 光源を実現するには高出力かつ大型の基本波光源を必 要としていた。 小型かつ高出力の紫外CWレーザーを実現 するには, 高効率紫外光変換が可能な非線形材料が必要 となるが, 紫外光領域で位相整合可能な非線形材料は非 常に限られている。一方, 可視短波長光への高効率変換 を実現する方法として, $\mathrm{LiNbO}_{3}(\mathrm{LN}), \mathrm{LiTaO}_{3}(\mathrm{LT})$, $\mathrm{KTiOPO}_{4}(\mathrm{KTP})$ などの強誘電体材料を用いた擬似位相整合
(Quasi-Phase Matching：QPM)による第二高調波発生 (Second Harmonic Generation：SHG) 素子(以下, QPM-SHG 素子と略す)が開発されている。QPMは非線形グレーティ ング周期を選ぶことで任意の波長におけるノンクリティ カル位相整合が可能であり，高い非線形定数である $d_{33}$ を 利用することができるため，高効率化に有利である。 LN, LT，KTPを用いた，導波路型あるいはバルク型の波 長変換素子により, 青紫色から赤色の可視および赤外領 域においては，高効率かつ高出力の波長変換が報告され ている1). さらに, QPM-SHG素子による紫外光発生も検 討されており，LTでは2次および1次のQPMを用いた波長 $340 \mathrm{~nm}$ の紫外光発生 ${ }^{2,3)}$, LN, KTPによるバルク型，ある いは導波路型の紫外光発生の報告4-6)がなされている。し かしながら，従来のQPM-SHG素子による紫外光発生で は，短波長領域での光損傷，グレートラック等の材料的 な問題と，紫外光発生に必要な短周期分極反転形成とい う技術的な問題があったため，出力は $1 \mathrm{~mW}$ 程度に限ら れ，高効率，高出力に限界があった。

我々はこれまでに上述した課題を解決するために，2 $\mathrm{mm}$ 厚Z板 $\mathrm{MgO}: \mathrm{LiNbO}_{3}$ (以下, $\mathrm{MgLN}$ )を用いた多重パルス 電界印加法を提案し, 紫外光用の高効率非線形材料であ るMgLNにおけるサブミクロンオーダの分極反転形成に成 功した ${ }^{7,8)}$ 。これにより，高効率な紫外光発生用のバルク 型QPM-SHG素子を実現した。今回，MgLNの分極反転特 性を明らかにし，それを基に分極反転形成モデルを提案 する。さらにこのモデルに基づき，短周期分極反転にお 
いて問題となる分極反転部の不均一な成長を抑圧する短 周期分極反転形成方法を述べる。本方法を用いてサブミ クロンオーダ $(0.8 \sim 1.2 \mu \mathrm{m})$ の分極反転形状制御に成功 し，MgLNの周期分極反転形成としては最短周期となる $1.4 \mu \mathrm{m}$ 周期を実現した。このようにして形成した周期分極 反転構造を用いてバルク型QPM-SHG素子を作製し, 広い 波長領域(波長340～390 nm) において高効率な紫外光発生 を確認した。 また，紫外光領域において理論值に近い実 効非線形定数をQPMで初めて達成した.

\section{Z板 $\mathrm{MgO}: \mathrm{LiNbO}_{3}$ の分極反転特性}

$\operatorname{MgLN}$ は非線形定数が大きく9)，短波長 $($ ～320nm) まで 透過し, 高い耐光損傷強度を有する ${ }^{10)}$, 優れた紫外用非 線形光学材料である.さらに, 分極反転しきい值電界(抗 電界)が低いため ${ }^{11)}$ ，低電圧での分極反転形成が可能であ る。しかしながら，Z板MgLNを用いた短周期分極反転形 成はノンドープLNやLTに比べて難しく，パターン電極を 利用した通常の電界印加方法での最短周期は $3.7 \mu \mathrm{m}^{12)}$, コ ロナポーリングを用いた場合でも $4.8 \mu \mathrm{m}$ 程度13)であり, Z 板MgLNにおける均一な短周期分極反転形成は難しかっ た.

我々は, パターン電極による電界印加方法におけるノン ドープLNとMgLNの分極反転特性を比較することでその 問題解決を図った。 Fig. 1 にZ板 $5 \mathrm{~mol} \% \mathrm{MgLN}(0.5 \mathrm{~mm}$ 厚) に周期 $3.5 \mu \mathrm{m}$ のパターン電極を形成し, 電界印加方法を用 いて形成した分極反転の写真を示す。写真は分極反転し た十Z面をウエットエッチングした結果である. 報告され ているノンドープLNの分極反転14) と比較して, 分極反転 部が不均一に拡大し, 周期状の分極反転構造は得られな かった. 分極反転特性の違いを明らかにするために, 電 界印加分極反転時の電流電圧特性の違いをノンドープLN とMgLNで比較した，電極面積 $1 \mathrm{~mm}^{2}$ 程度の平面電極を $\mathrm{Z}$ 板ノンドープLN(0.15 mm厚), およびZ板 $5 \mathrm{~mol} \% \mathrm{MgLN}$ (0.4 mm厚)の $\pm Z$ 面に形成し，自発分極に対向する電界(ノ ンドープLN：20 kV/mm, MgLN：6 kV/mm)を絶縁液中

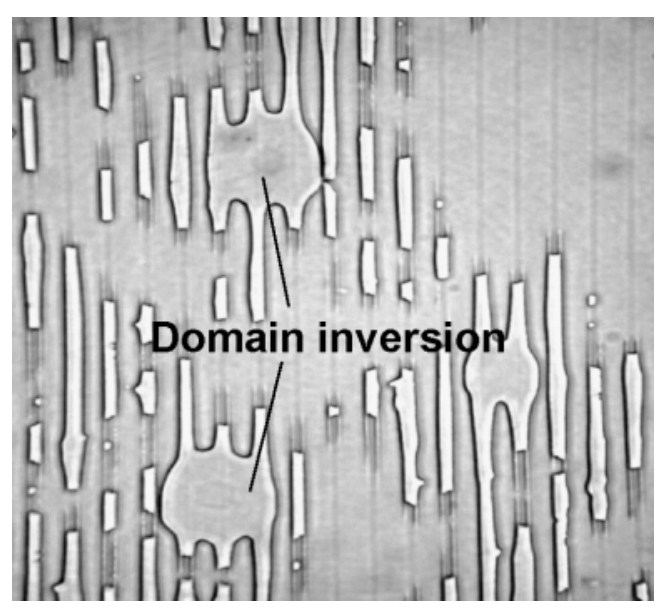

Fig. 1 Micro-photograph of domain inversion of $+\mathrm{Z}$ surface in $\mathrm{MgO}: \mathrm{LiNbO}_{3}$ fabricated by conventional method.
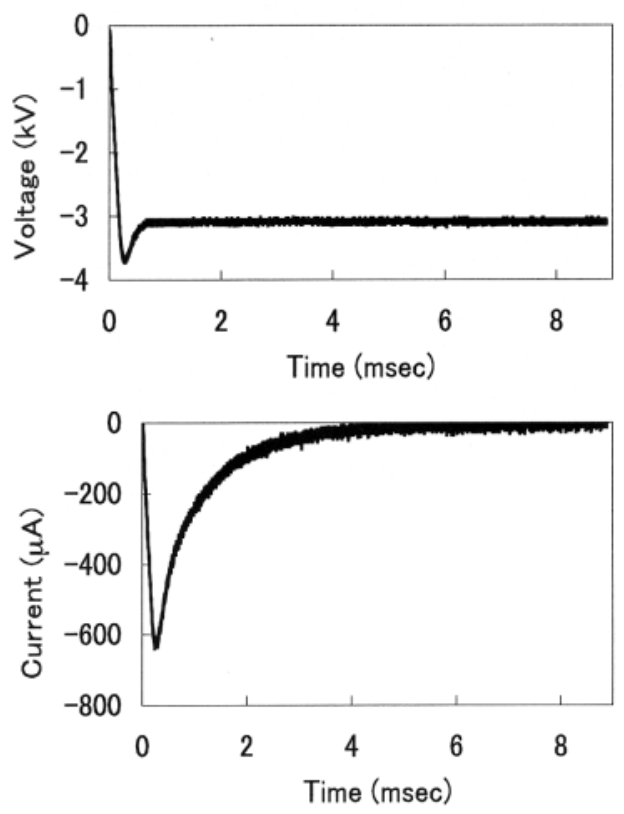

(a)
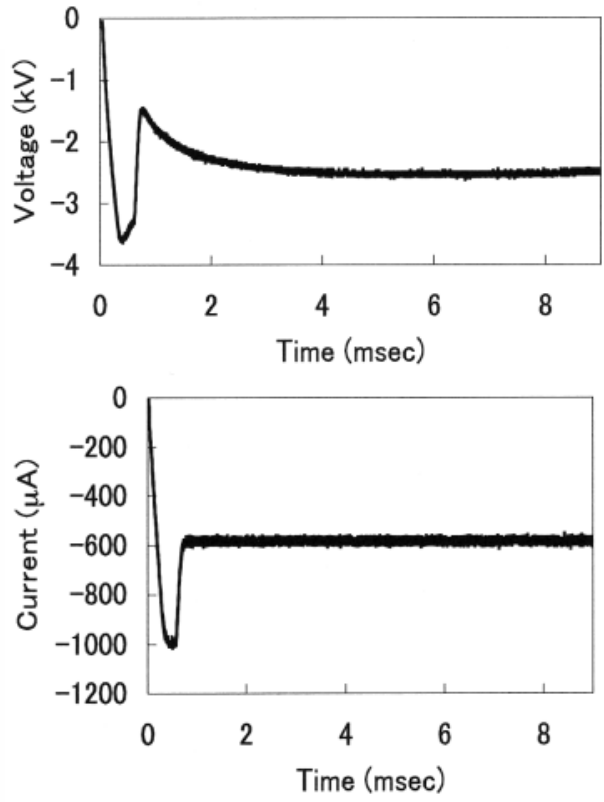

(b)

Fig. 2 Voltage and current waveforms for poling (a) nondoped $\mathrm{LiNbO}_{3}$ and (b) $5 \mathrm{~mol} \% \mathrm{MgO}: \mathrm{LiNbO}_{3}$ at room temperature.

(室温)で印加した. Fig. 2に印加電圧と分極反転時に流れ る反転電流の測定結果を示す。（a）はノンドープLN，（b） は5 mol\% MgLNの場合である。ノンドープLNの場合, 印 加直後に電流が流れるがその後電流值は減少し, 電極下 の分極反転形成が終了する約 $4 \mathrm{msec} て ゙$ 電流值は0になっ た。一方, MgLNは電界印加と同時に電流が流れはじめ, 観測中 (数分間), 電流の減少は見られなかった. 強誘電体 における分極反転による電荷の移動は内部電荷と表面電 荷の合計で表され, 分極反転した面積を $S$ とすると移動電 荷量 $Q$ は, $Q=2 P \mathrm{~s} \times S(P \mathrm{~s}$ は自発分極の值 $)$ の関係が成り立 $つ^{15)}$. (a)の場合, ノンドープ LNのPs $=70 \mu \mathrm{C} / \mathrm{cm}^{2}{ }^{5)}$ か ら計算して, 約 $1 \mathrm{~mm}^{2}$ の分極反転部を形成するための電荷 


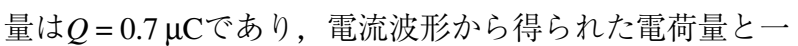
致した。一方，(b)の場合, $\mathrm{MgLN} の P \mathrm{~s}=80 \mu \mathrm{C} / \mathrm{cm}^{2}{ }^{11)}$ に 対しては，電極面積の 10 倍以上の分極反転領域が形成可 能な電荷量を供給したことになる。しかしながら, 形成 された分極反転面積は電極とほぼ同程度であった。

以上の実験結果はMgLNの分極反転特性が通常の強誘電 体結晶における特性とは異なり，分極反転形成に伴った 電気特性の変化が生じていることが推測される。そこ で, $1 \mathrm{~mm}$ 厚Z板MgLNの $\pm \mathrm{Z}$ 面に面積 $1 \mathrm{~mm}^{2}$ の電極を形成 し, 分極反転形成前後におけるZ板 $\mathrm{MgLN}$ の電気抵抗の変 化を測定した．測定は分極反転しきい值電界以下の-400〜 $+400 \mathrm{~V} / \mathrm{mm}$ の範囲で行った。分極反転形成前, MgLNは絶 縁体特性を示し，電流は観測されなかった $($ Fig. 3(a))。一 方, 分極反転形成直後はFig. 3(b) に示すように, 電圧に比 例する電流が流れ，電気抵抗が $700 \mathrm{k} \Omega$ 程度に大幅に低下し ていることがわかった．抵抗測定による分極反転面積の 増大がないこと, 正負方向どちらの電界に対しても電流 が流れることより，電流は分極反転形成に伴う電荷の移 動とは無関係であり，分極反転部自体の電気抵抗が変化 していることを示している．また，分極反転形成直後の 抵抗率は $7 \times 10^{5} \Omega \cdot \mathrm{mm}$ であった，X板 MgLNでは分極反転 形成後に整流特性 (ダイオード特性)が確認されている が16), Z板MgLNではその特性とは異なり, 分極反転形成 によってMgLNが絶縁体から半導体に近い抵抗率を有する 特性に変化していることが明らかになった。この分極反 転形成に伴う抵抗率の変化については, 原理的に明らか にされていないが, 分極反転部自体が抵抗率の変化を誘 起する結晶構造の変化を伴わないことから, 向きの異な る分極が隣接する分極壁における結晶構造の变化が起因 しているものと考察される.

さらに，分極反転形成後の $\mathrm{MgLN}$ こおける抵抗率の時間 特性を評価した. Fig. 4は分極反転形成直後の抵抗率の変 化を示したものである．分極反転直後大きく低下してい た抵抗率は時間とともに増加していく. 分極反転形成に 伴うMgLNの抵抗率の変化は, 比較的不安定な現象であ り，時間とともに緩和されることがわかった。均一な分 極反転を形成するには, 電気特性の時間的な変化は好ま しくない，安定な分極反転条件を確立するには，短時間 で分極反転形成プロセスを終了するのが望ましい.

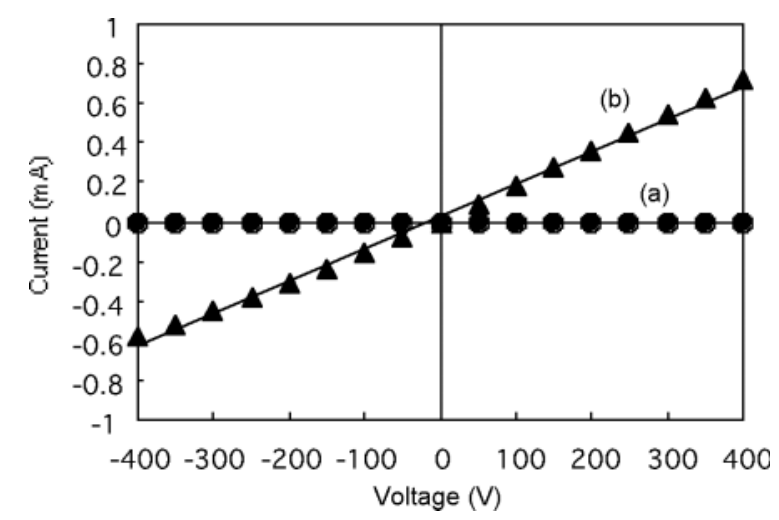

Fig. 3 Electric property of (a) as grown $\mathrm{MgO}: \mathrm{LiNbO}_{3}$ and (b) selectively poled $\mathrm{MgO}: \mathrm{LiNbO}_{3}$.

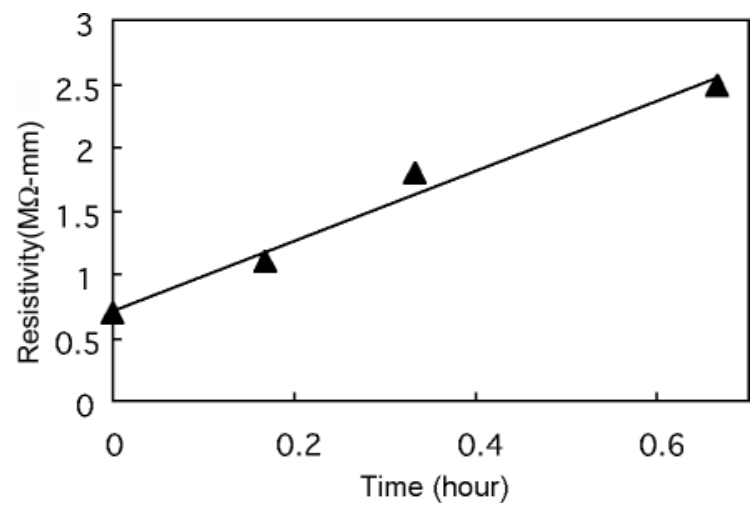

Fig. 4 Time dependence of resistivity in Z-cut $\mathrm{MgO}: \mathrm{LiNbO}_{3}$ after forming the domain inversion by the electric poling method.

\section{3. $\mathrm{MgO}: \mathrm{LiNbO}_{3}$ での短周期分極反転形成方法}

前章の実験結果より明らかになった分極反転にともな う抵抗率の変化を基にMgLNの分極反転特性のメカニズム を提案する. 抵抗率の変化を考慮すると, パターン電極 による電界印加時に発生する不均一な分極反転特性が説 明できる．Fig. 5に，提案したMgLNにおける分極反転形 成のメカニズムを示す。パターン電極に印加する電界強 度が分極反転しきい值電界強度を上回ると分極反転核が +Z面電極下にランダムに発生する.さらに電界印加を継 続するとランダムに発生した分極反転核から-Z方向に分極 反転領域が成長し，-Z面(基板裏面)へ貫通する，分極反転 部分は抵抗值が極端に低下するため，貫通した分極反転 部分に電流が集中し，電流集中部分において局所的に分 極反転が拡大する。貫通した分極反転部分により電圧降 下が発生するため, 分極反転の成長が遅れた部分は成長

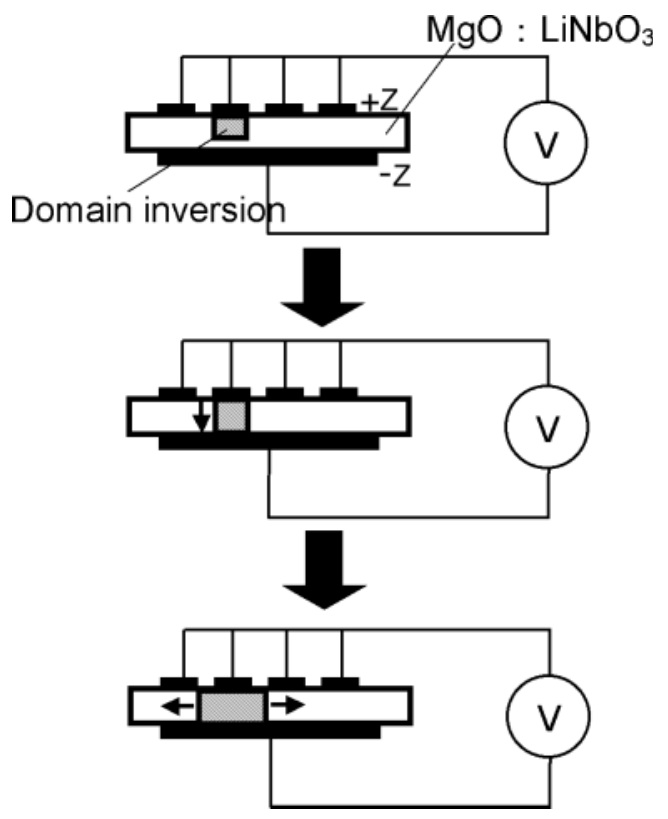

Fig. 5 Formation process of non-uniform periodically poled $\mathrm{MgO}: \mathrm{LiNbO}_{3}$ caused by local penetration of domain inversion. 
が停止する. 以上の結果, 電極下に局所的に発生する分 極反転の成長は, 電極下全体にわたり均一な分極反転が 形成されるのを困難にする。すなわち，局所的に発生す る貫通分極反転部分が，パターン電極を用いた電界印加 法における均一な分極反転形成を困難にしていると考え られる。

我々は分極反転の裏面への貫通を回避する電界印加分 極反転形成方法を提案する。新しいアプローチは，二つ の方法からなる. 第一は, $\mathrm{MgLN}$ 基板の厚板化である. 通 常のLN, LTでは短周期分極反転構造形成には基板の薄板 化が有効であった ${ }^{3-5,17)}$. しかし，MgLNでは分極反転部の 裏面への貫通を防止するために，厚板MgLNを用いること が有効である，MgLNは分極反転しきい值電界が低いた め，厚板への高電界印加が容易である，第二は，多重パ ルス印加法の適用である。多重パルス印加法はオフカッ 卜基板で提案されているが18), 短パルス列を印加するこ とで，厚み方向の分極反転成長を抑制し，多重パルス化 により，横方向，厚み方向の分極反転領域を制御するこ とが可能である，横方向，厚み方向の分極反転領域の制 御は, ノンドープLNでは電荷量による制御で行うことが 可能であるが，MgLNでは分極反転形成に伴い抵抗率が著 しく低下するため, 電荷量によって制御することができ ない.よって, 分極反転領域の制御は, 印加パルス回数 を最適化し, 最適パルス回数を決定することでおこなっ た。

以上の提案した手法を用い, 短周期分極反転形成を試 みた. Fig. 6に, 短周期分極反転形成の作製プロセスを示 す。基板は $2 \mathrm{~mm}$ 厚Z板 $5 \mathrm{~mol} \% \mathrm{MgO}: \mathrm{LiNbO}_{3}$ 結晶を使用し た。まず，MgLNの+Z面にTa膜を $100 \mathrm{~nm}$ 成膜する。次 に，フォトリソグラフィ， $\mathrm{CF}_{4}$ ドライエッチングにより， 周期状パターン電極を+Z面に形成する (Fig. 6 (a)) . +Z面 に電極カバーとして $\mathrm{SiO}_{2}$ 膜を $300 \mathrm{~nm}$ 成膜し, 裏面電極とし て-Z面にTa膜を $100 \mathrm{~nm}$ 成膜する (Fig. 6 (b)). 分極反転形 成は前述した多重パルス印加法を用いた (Fig. 6 (c)). 電 界印加条件は印加電圧 $10 \mathrm{kV}$ ，パルス幅 $1 \mathrm{msec}$ とた。電

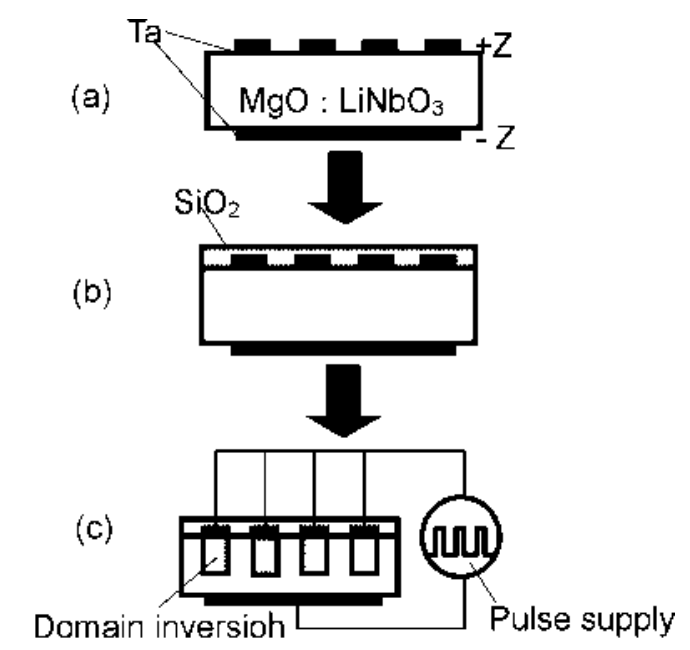

Fig. 6 Fabrication process utilizing multi-pulse poling method in a thick substrate for short periodically poled $\mathrm{MgO}: \mathrm{LiNbO}_{3}$.
界印加中の基板温度を上げることで，分極反転しきい值 電界を $5 \mathrm{kV} / \mathrm{mm}$ 以下に低減し, 厚板の結晶においても高電 圧印加による結晶損傷を回避できる19)。絶縁液 (フッ素系 不活性液体 (フロリナート))を加熱することで基板温度を $100{ }^{\circ} \mathrm{C}$ した。

以上の条件で作製した周期 $1.4 \mu \mathrm{m}$ の短周期分極反転の断 面写真をFig. 7に示す. 分極反転部の形状観察は結晶断面 を鏡面研磨後, $60{ }^{\circ} \mathrm{C}$ フッ硝酸液 $\left(\mathrm{HF}: \mathrm{HNO}_{3}=2: 1\right)$ によ り 5〜10分間エッチングすることで可視化した. Fig. 7で示 されるように+Z面から深さ $0.2 \mathrm{~mm}$ 付近まで均一な分極反 転が得られている。 また, 深さ方向の分極反転成長は 0.2 $\sim 0.5 \mathrm{~mm}$ に抑制され，裏面への分極反転の貫通は確認さ れなかった. 周期方向の分極反転部の幅は $0.8 \mu \mathrm{m}$ 程度であ り，Z板MgLNにおいて初めてサブミクロンオーダの分極 反転部の形成に成功した。提案した分極反転形成方法を 用いることで，裏面への分極反転の貫通を防止し, MgLN の最短周期 $(1.4 \mu \mathrm{m})$ の分極反転を $10 \mathrm{~mm}$ 以上の長さに渡っ て均一に形成することが可能となった。

この技術は, 分極反転構造を利用した擬似位相整合デ

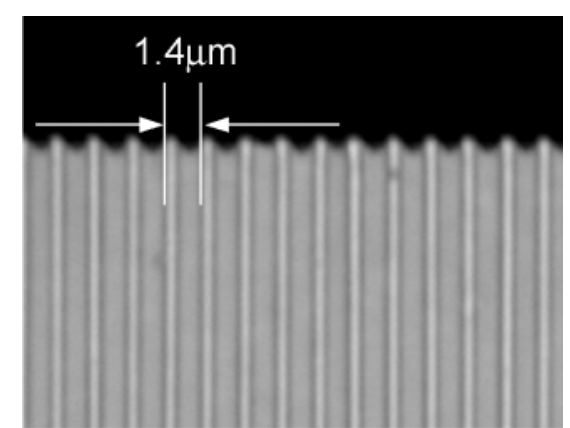

(a)

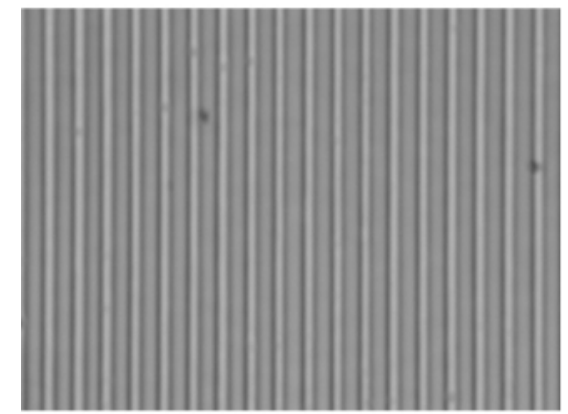

(b)

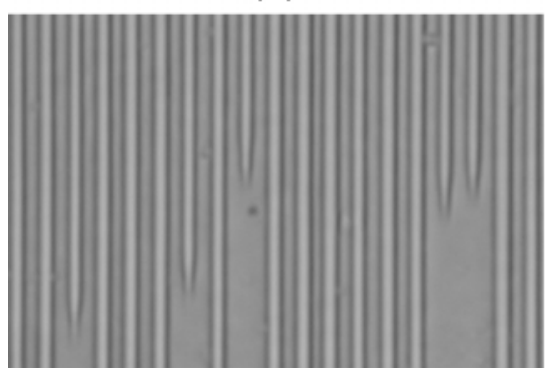

(c)

Fig. 7 Cross-sectional micro-photographs of a first-order periodically poled $\mathrm{MgO}: \mathrm{LiNbO}_{3}$ with $1.4 \mu \mathrm{m}$ period (a) near the surface, (b) at the depth of $0.15 \mathrm{~mm}$, and (c) at the depth of $0.2 \mathrm{~mm}$, as seen on $\mathrm{y}$-face. 
バイス等への応用に限らず, 電気光学デバイス, 強誘電 体メモリ等の新たな展開を可能にするものである.

\section{4. 高効率紫外光発生}

前述した分極反転形成方法を用い，周期 $1.4 \sim 2.4 \mu \mathrm{m}$, 作用長 $10 \mathrm{~mm}$ の周期分極反転構造を有する紫外用バルク QPM-SHG素子を作製し，その特性を評価した。

基本波に連続発振の $\mathrm{Ti}: \mathrm{Al}_{2} \mathrm{O}_{3}$ レーザーを用いて，シング ルパス波長変換により, QPM-SHG素子の特性を室温で評 価した(Fig. 8). 集光レンズの焦点距離は48 mmであり,

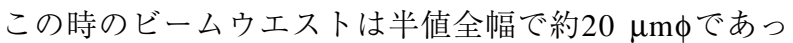
た。最短周期 $1.4 \mu \mathrm{m}$ のバルク QPM-SHG素子では，波長 685 $\mathrm{nm}$ の基本波に対しピーク出力が得られた. 最大出力は 3.5

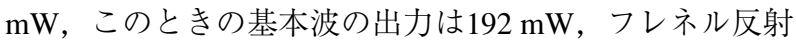
を考慮する変換効率は $8.6 \% / \mathrm{W}$ ，変換効率から計算した実

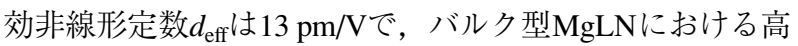
効率342 $\mathrm{nm}$ 紫外光発生に成功した。

周期1.4 2.4 $\mu \mathrm{m}$ のバルク QPM-SHG素子における紫外光 出力は $\mathrm{Ti}: \mathrm{Al}_{2} \mathrm{O}_{3}$ レーザーの最大入力パワーに依存してお り，基本波入力パワーが最も高い基本波波長 $744 \mathrm{~nm} に お ~$ いて紫外SH出力 (波長 $372 \mathrm{~nm}$ ) はシングルパス発生で72 $\mathrm{mW}$ ，このときの基本波出力は $622 \mathrm{~mW}$, 変換効率は 16.7 $\% / \mathrm{W}$ あ゙った。また，実効非線形定数 $d_{\mathrm{eff}}$ は2 $20.6 \mathrm{pm} / \mathrm{V}$ (理

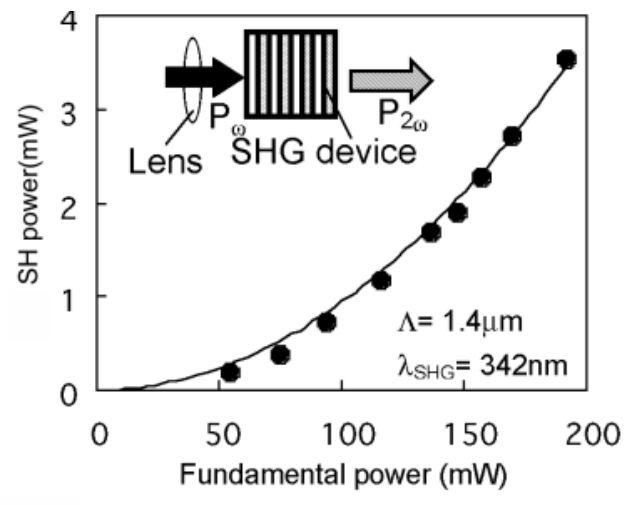

(a)

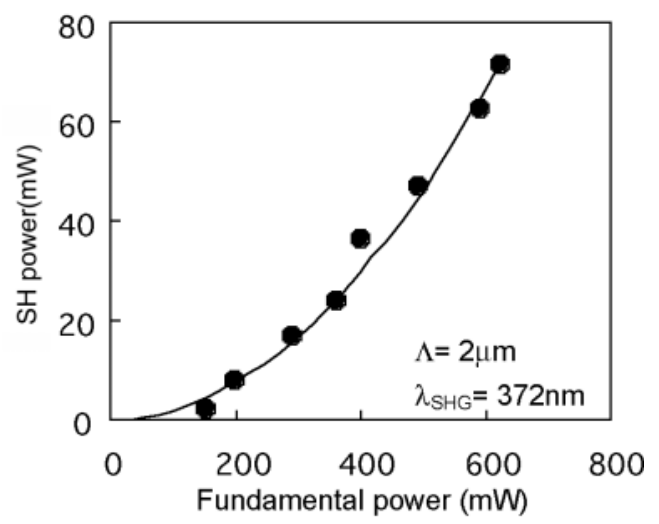

(b)

Fig. 8 Measured SH power plotted against the fundamental power in a single pass through the bulk QPM-SHG devices. The line shows the quadratic relation.
論值 $\left.d_{\mathrm{eff}}=21.6 \mathrm{pm} / \mathrm{V} ; d_{\mathrm{eff}}=2 / \pi \times d_{33}, d_{33}=34 \mathrm{pm} / \mathrm{V}\right)$ は, 紫 外光領域において, 今までに非線形材料で得られた最大 の值であり, 理想的な周期分極反転構造が素子全体に渡 り均一に形成されていることを示している。

$\mathrm{SH}$ 出力は基本波出力の二乗に比例し, 光損傷のない安 定かつ高効率な紫外光発生を確認した。 得られた変換効 率は従来の紫外用波長変換素子の効率に対し二桁高い值 であり，紫外域で初めて高効率な波長変換に成功した。

Fig. 9は波長と変換効率の関係をプロットしたものであ る. 実線は $d_{\mathrm{eff}}=21.6 \mathrm{pm} / \mathrm{V}$ としときの変換効率の理論值 である，波長362 nm以上では，ほぼ理論值に近い值を示 しており，分極反転周期 $1.8 \mu \mathrm{m}$ 以上(波長 $362 \mathrm{~nm}$ 以上)では 理想的な周期分極反転構造が実現されている。波長 355 $\mathrm{nm}$ 以下では実験值は理論值に比べ低下している。これ は，短周期分極反転構造におけるデューティ比が50\%か らずれてきていること，および結晶の吸収端に近づくた め結晶内での高調波の吸収ロスが増大していることが原 因と考えられる。

\section{5. まとめ}

高効率な紫外用波長変換素子の実現を目的として, 新 たな高効率非線形光学デバイスを開発した。従来困難で あった高非線形光学材料への紫外用周期分極反転を実現 するために，MgLNにおける電界印加分極反転の課題を明 らかにし, 分極反転時の不均一化の要因となる分極反転 形成モデルを提案した。 さらに，このモデルを基に短周 期分極反転形成方法を考案した. $2 \mathrm{~mm}$ 厚Z板MgLNの導入 と多重パルス印加方法を用いることで基板裏面への分極 反転の貫通を防止し, MgLNで初めてサブミクロンオーダ (分極反転領域幅: 約 $0.8 \mu \mathrm{m}$ )の分極反転形成に成功した. この方法を用いて，周期1.4 2.4 $\mu \mathrm{m}$ ，相互作用長 $10 \mathrm{~mm}$ の 均一な短周期分極反転構造を有する波長340～390 nmに対 応するバルク QPM-SHG素子を作製し, 最大出力 $72 \mathrm{~mW}$, 効率 $16.7 \% / \mathrm{W}$ (波長 $372 \mathrm{~nm}$, 分極反転周期 $2 \mu \mathrm{m}$ ) の高効率 な紫外光発生を確認した.

これらの結果は, MgLNを用いたバルク QPM-SHG素子 が，高い非線形光学定数を持った新しい紫外光源用結晶

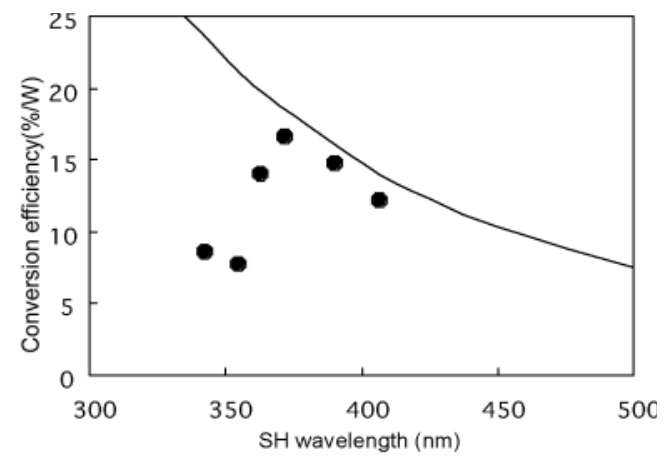

Fig. 9 Measured normalized conversion efficiency as a function of the SH wavelength. The dots show the experimental result of normalized conversion efficiency. Solid line shows theoretical curve calculated using $d_{\text {eff }}$ of $21.6 \mathrm{pm} / \mathrm{V}$. 
として，光源の小型化，高効率化の可能性を有すること を示している．赤色半導体レーザーと組み合わせること で，従来困難であった小型計測用光源をはじめ，光記録 用光源への展開が可能である。さらに, 優れた耐光損傷 性を利用した高出力化への応用も可能であり, 高出力固 体レーザーの波長変換により, 画像表示装置, 露光, 加 工等，多くの分野への応用が期待できる.

\section{参考文献}

1) D. H. Jundt, G. A. Magel, M. M. Fejer, and R. L. Byer: Appl. Phys. Lett. 59 (1991) 2657.

2) K. Mizuuchi and K. Yamamoto: Opt. Lett. 21 (1996) 107.

3) K. Mizuuchi, K. Yamamoto, and M. Kato: Appl. Phys. Lett. 70 (1997) 1201.

4) M. Fujimura, T. Suhara, and H. Nishihara: Bull. Mater. Sci. 22 (1999) 413.

5) K. Kintaka, M. Fujimura, T. Suhara, and H. Nishihara: Electron. Lett. 32 (1996) 2237.

6) S. Wang, V. Pasiskevcius, J. Hellstrom, F. Laurell, and H. Karlsson: Opt. Lett. 24 (1999) 978.
7) K. Mizuuchi, A. Morikawa, T. Sugita, and K. Yamamoto: Jpn. J. Appl. Phys. 42 (2003) L90.

8) K. Mizuuchi, A. Morikawa, T. Sugita, and K. Yamamoto: Opt. Lett. 28 (2003) 935.

9) W. J. Kozlovsky, E. K. Gustafson, R. C. Eckardt, and R. L. Byer: Opt. Lett. 13 (1988) 1102

10) Y. Furukawa, K. Kitamura, S. Takekawa, K. Niwa, and H. Hatano: Opt. Lett. 23 (1998) 1892.

11) A. Kuroda, S. Kurimura, and Y. Uesu: Appl. Phys. Lett. 69 (1996) 1565.

12) K. Mizuuchi, K. Yamamoto, and M. Kato: Electron. Lett. 32 (1996) 2091.

13) A. Harada, Y. Nihei, Y. Okazaki, and H. Hyuga: Opt. Lett. 22 (1997) 805 .

14) M. Yamada, N. Nada, M. Saitoh, and K. Watanabe: Appl. Phys. Lett. 62 (1993) 435

15) K. Kintaka, M. Fujimura, T. Suhara, and H. Nishihara: J. Lightwave Technol. 14 (1996) 462.

16) S. Sonoda, I. Tsuruma, and M. Hatori: Appl. Phys. Lett. 70 (1997) 3078.

17) K. Mizuuchi and K. Yamamoto: Appl. Phys. Lett. 66 (1995) 2943

18) T. Sugita, K. Mizuuchi, Y. Kitaoka, and K. Yamamoto: Jpn. J. Appl. Phys. 40 (2001) 1751.

19) H. Ishizuki, T. Taira, S. Kurimura, J. H. Ro, and M. Cha: Jpn. J. Appl. Phys. 42 (2003) L108. 